J. Japan. Assoc, Min.

Petr. Econ. Geol.

70, $388-394,1975$

\title{
AWARUITE, HEAZLEWOODITE, AND NATIVE COPPER IN SERPENTINIZED PERIDOTITE FROM THE MINEOKA DISTRICT, SOUTHERN BOSO PENINSULA
}

\author{
KEIICHIRO KANEHIRA \\ Department of Earth Sciences, Chiba University. Chiba \\ Shohei Banno \\ Department of Earth Sciences, Kanazawa University, Kanazarıa \\ SHUNzo YuI \\ Department of Mining Geology, Akita University, Akita
}

\begin{abstract}
Awaruite was found in serpentinized peridotites from the Mineoka district, southern Boso Peninsula. The mineral occurs invariably in serpentinized parts of the rocks, indicating that it was formed in the course of serpentinization. Heazlewoodite and native copper were formed also in association with awaruite during serpentinization. Chemical analysis of the awaruite yields the formula: $\mathrm{Ni}_{\mathbf{2 . s 6}} \mathrm{Fe}$. Native copper associated with heazlewoodite contains about 5 weight percent nickel. The occurrence of awaruite suggests that oxygen fugacity of fluid being responsible to serpentinization was lowered at least locally down to $10^{-42}$ bar during serpentinization. The low oxygen fugacity of fluid was resulted from reaction between fluid and fayalite component of olivine producing magnetite and serpentine minerals.
\end{abstract}

\section{INTRODUCTION}

Awaruite has been found in serpentinized peridotites from various localities of the world (Ramdohr, 1967). The mineral occurs not in unaltered peridotites but invariably in serpentinized rocks. This fact has been considered to indicate that awaruite was formed in the course of serpentinization of the ultramafic rocks (Nickel, 1959; Kanehira et al., 1964; Chamberlain et al., 1965; Ramdohr, 1967). The widespread occurrence of awaruite in serpentinized rocks suggests a reducing condition of serpentinization.

We found awaruite, heazlewoodite, and native copper in serpentinized peridotites from the Mineoka district, southern Boso Peninsula. In this brief paper we intend to describe modes of occurrence and some properties of the minerals and to discuss the formation environment of the minerals.

\section{Geologic SETTING AND host Rocks}

A geologic sketch map of the Mineoka district is shown in Figure 1. In the Mineoka district probable Paleogene sediments called the Mineoka Group are exposed in a zone extending in E-W direction. The Mineoka Group consists of siliceous shale, sandstone, alternation of shale and sandstone, and subordinate 


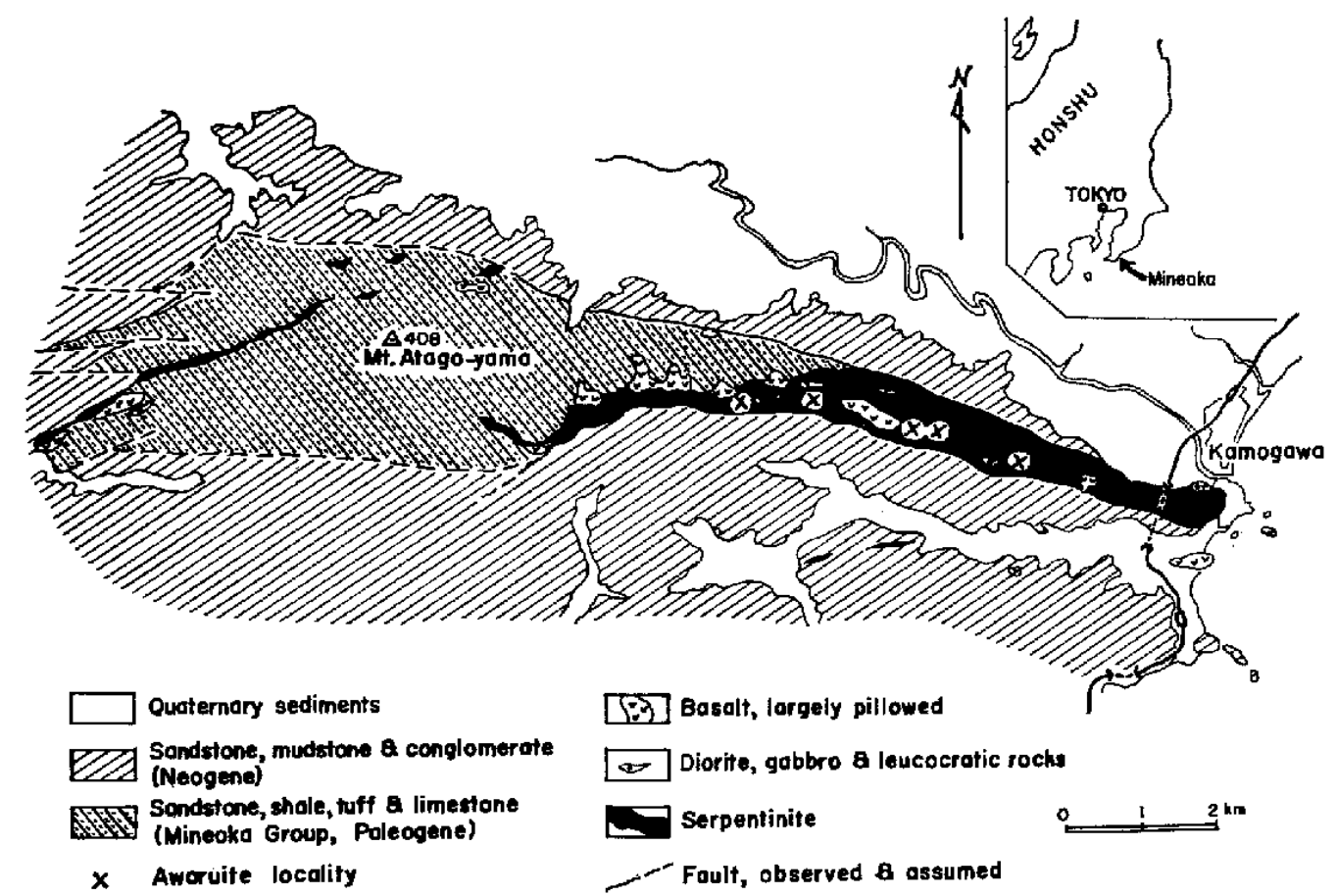

Fig. 1. Geologic sketch map of the Mineoka district, southern Boso Peninsula.

amounts of impure limestone and tuff. The folded Mineoka Group is faulted and flanked by Neogene calstic sediments on both the north and south sides. Ultramafic rocks are intruded in the Mineoka Group and the Neogene sediments, and are exposed either in two narrow zones or in small isolated masses. The primary intrusion has taken place in Miocene age, but later movement cannot be denied. Basic extrusives composed largely of pillowed basalt, pillow breccia, and dolerite dikes are exposed in association with the ultramafic rocks.

The largest mass of the ultramafic rocks is about $700 \mathrm{~m}$ in maximum width and extends about $9 \mathrm{~km}$ in E-W direction. The mass comprises serpentinized peridotite and a number of lens-shaped bodies of various sizes of diorite, gabbro, gabbro pegmatite, and leucocratic rocks. We collected 40 fragments of peridotite from various parts of the ultramafic mass, and examined them under the reflectcd light microscope. Awaruite was found in $\mathbf{5}$ specimens, heazlewoodite in 4 , and native copper in 6 . Awaruite localities are shown in Figure 1.

Ultramafic rocks are extensively serpentinized, but primary minerals are preserved to some extent. In most part of the ultramafic mass 70 to 80 volume percent of the rocks are serpentinized. In part the rocks are completely serpentinized. Primary minerals are olivine $\left(\mathrm{F}_{88-91}\right)$, rhombic pyroxene and subordinate amount of monoclinic pyroxene. Chromite and a small amount of pentlandite are contained sporadically. Pentlandite grains are anhedral and interstitial against primary silicate minerals. This suggests that the mineral is a primary constituent of the ultramafic rocks. Olivine is altered to 
serpentine which is always accompanied by fine-grained crystals of magnetite.

\section{MODES OF OGGURRENGE}

Awaruite is white and bright under the reflected light microscope. Two distinct modes of occurrence are observed, i.e., the mineral occurs as minute grains included in secondary magnetite formed by serpentinization of peridotite in some cases (Fig. 2-A), and it occurs also in association with pentlandite in other cases (Fig. 2-B). The awaruite inclusions in magnetite are usually about a few microns in size. In one specimen, awaruite coexists with heazlewoodite in the inclusions surrounded by magnetite. When awaruite occurs in association with pentlandite, the former exists along the rim of the latter. In some cases pentlandite grains are armoured by the thin crusts of awaruite as is shown in Figure 2-C. The crusts of awaruite are usually about 3 microns thick.

Heazlewoodite is cream-coloured with yellowish tint, slightly brighter than associated pentlandite but darker than awaruite. The mineral occurs in association with awaruite in inclusions within
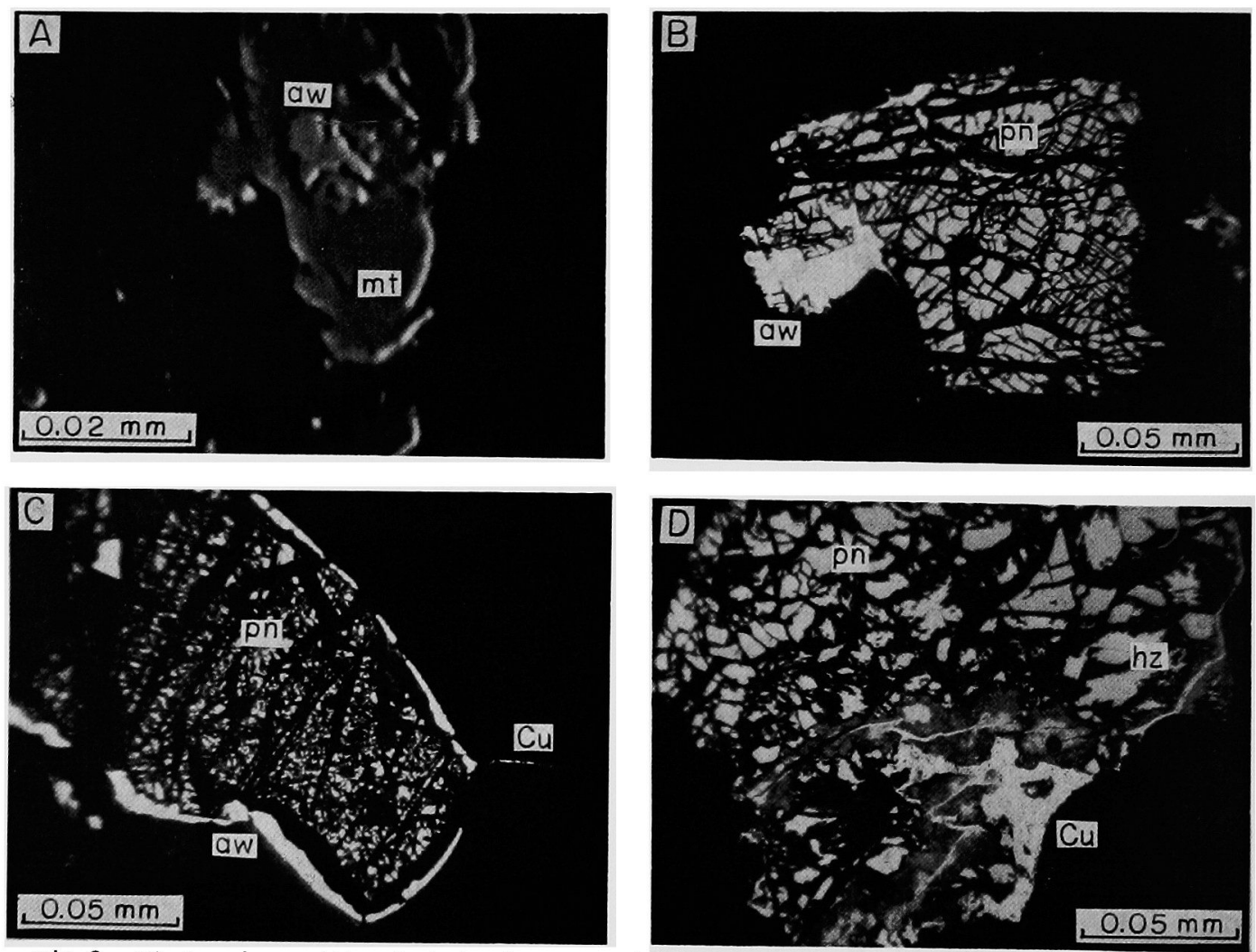

Fig. 2. Electron image (A) and photomicrographs (B, C and D) of awaruite and associated minerals.

(A) An inclusion of awaruite (aw) in magnetite (mt).

(B) Awaruite (aw) formed in contact with pentlandite (pn).

(C) Pentlandite (pn) armoured by awaurite (aw).

Minute stringers of native copper $(\mathrm{Cu})$ are formed adjacent to pentlandite and awaruite.

(D) Pentlandite $(\mathrm{pn})$ is replaced by unidentified grey minerals along cracks. Heazlewoodite $(\mathrm{hz})$ and native copper $(\mathrm{Cu})$ are formed in the peripheral zone of pentlandite grain. 
Awaruite, heazlewoodite, and native copper in serpentinized peridotite from the Mineoka district 391

magnetite grains or in association with pentlandite as is shown in Figure 2-D.

Native copper is pink and considerably bright under the microscope. The mineral occurs as minute stringers or streaks isolated in serpentine aggregate and also adjacent to pentlandite grains.

\section{Ghemigal composition}

A grain of awaruite associated with pentlandite, which is shown in Figure 2-B, was analyzed with the Hitachi electron probe microanalyzer with a take off angle of $40^{\circ}$. Pure metals of iron and nickel were used as standards. The measured values were corrected by the procedure as described by Sweatman and Long (1969) modified by the method of Colby (1966) for $F(x)$, and by that of Springer (1967) for the effect of the continuous fluorescence. The result is shown in Table 1 . The analysis of the awaruite yields the formula: $\mathrm{Ni}_{\mathbf{2 . 2 6}} \mathrm{Fe}$.

In a specimen of serpentinite, an aggregate of pentlandite, heazlewoodite, and native' copper was observed (Fig. 2-D). The shape of the aggregate indicates that the primary pentlandite is formed in interstices among silicate minerals. The pentlandite is altered along cracks to a dark grey minerals and partly replaced by heazlewoodite, and an irregular-shaped grain of native copper is formed in the rim of the pentlandite grain. Each of the three metallic minerals was analyzed with the JXA-5 electron probe microanalyzer with a take off angle of $40^{\circ}$. A pure metallic nickel and an analyzed crystal of natural chalcopyrite were used as standards. The measured values were corrected by the procedure similar to that mentioned above. The results together with normalized atomic composition of the minerals are tabulated in Table 1.

Table 1. Microprobe analyses of native metals and sulphides in serpentinites from the Mineoka district.

\begin{tabular}{|c|c|c|c|c|c|c|c|}
\hline & \rceil$^{*}$ & $2^{* *}$ & $3^{* *}$ & $4^{\star \star}$ & $5^{\star \star}$ & $6 * \star$ & $7^{\star \star \star}$ \\
\hline & Awaruite & Copper & Copper & $\begin{array}{l}\text { Heazle- } \\
\text { woodite }\end{array}$ & $\begin{array}{l}\text { Heazle- } \\
\text { woodite }\end{array}$ & $\begin{array}{l}\text { Pent- } P \\
\text { Tandite }\end{array}$ & $\begin{array}{l}\text { Pent- } \\
\text { e landite }\end{array}$ \\
\hline \multicolumn{8}{|c|}{ Weight percent } \\
\hline $\mathrm{Cu}$ & $-\infty$ & 92.8 & 93.1 & 0.1 & 0.1 & 0.1 & 0.1 \\
\hline $\mathrm{Fe}$ & 29.5 & 1.2 & 1.1 & 1.8 & 2.1 & 24.3 & 24.6 \\
\hline $\mathrm{Ni}$ & 70.0 & 5.5 & 4.5 & 71.4 & 71.4 & 41.2 & 41.0 \\
\hline Co & -- & -- & --- & 0.0 & 0.1 & 0.5 & 0.6 \\
\hline$s$ & -- & -- & -- & 25.2 & 25.4 & 31.7 & 31.5 \\
\hline Total & 99.5 & 99.5 & 98.7 & 98.5 & 99.1 & 97.8 & 97.8 \\
\hline \multicolumn{8}{|c|}{ Normalized atomic percent } \\
\hline $\mathrm{Cu}$ & -- & 92.8 & 93.9 & 0.1 & 0.1 & 0.7 & 0.1 \\
\hline $\mathrm{Fe}$ & 30.6 & 1.3 & 1.3 & 1.6 & 1.9 & 20.4 & 20.6 \\
\hline $\mathrm{Ni}$ & 69.4 & 5.9 & 4.8 & 59.7 & 59.3 & 32.9 & 32.7 \\
\hline Co & $\cdots$ & --- & -- & 0.0 & 0.1 & 0.4 & 0.5 \\
\hline$S$ & $\cdots$ & $m$ & -- & 38.6 & 38.6 & 46.2 & 46.1 \\
\hline
\end{tabular}

* Specimen No. 35

** Specimen No.50. Analyses were made in two different grains of each minerat in one and the same mineral aggregate. 
Analyses were made for two different grains of each mineral in the mineral aggregate. The analyses indicate that each of the minerals is fairly uniform in chemical composition within one and the same mineral aggregate. The atomic ratio of nickel to iron in the analyzed pentlandite is 1.6. The pentlandite is a nickel-rich variety. The number of metal atoms contained in the analyzed heazlewoodite in respect to 2 atoms of sulphur is $\mathbf{3 . 1 8}$. The mineral is somewhat sulphur deficient as compared with stoichiometric heazlewoodite. The analyzed native copper contains 5 to 6 atomic percent nickel and 1.3 atomic percent iron and forms a homogeneous alloy.

The grey minerals filling the cracks of pentlandite and surrounding heazlewoodite and native copper grains are one silicate phase, possibly serpentine, and an unidentified nickel-iron-bearing mineral. Microprobe analysis indicates that the latter mineral contains neither sulphur nor silicon. The mineral is assumed to be a nickel-iron oxide but is not identified with any confidence.

\section{ORIGIN OF THE AWARUITE AND ASSO- GIATED MINERALS}

Nickel (1959) studied awaruite-bearing serpentinized peridotite from the Eastern Townships, Quebec Province, Canada. Fine-grained awaruite was associated with serpentine and magnetite. Nickel content of the olivine was $0.22-0.24$ percent, while that of the associated serpentine was 0.090.11 percent. Then he considered that a considerable amount of nickel in primary silicates of peridotite was liberated during serpentinization to form awaruite. On the other hand, Chamberlain et al. (1965) observed pentlandite grains armoured by awaruite in serpentinized peridotite of the Muskox intrusion in northern Canada. They considered that the peridotite was desulphurized during serpentinization and pentlandite, a primary constituent of the peridotite, was altered in its periphery to awaruite.

In the serpentinite from the Mineoka district awaruite occurs either in association with secondary magnetite or along the rim of pentlandite grains. The pentlandite grains are interstitial against primary silicates, olivine and pyroxenes. Pentlandite is probably one of the primary constituents. The pentlandite grains are altered along their cleavage and cracks, sometimes replaced partly by heazlewoodite and native copper, and rarely surrounded by thin awaruite layer. Nickel and or iron of secondary metallic minerals may have been derived from pentlandite as suggested in the Muskox intrusion by Chamberlain et al. (1965).

Some of the awaruite grains do not show any direct spatial relation to the pentlandite, but are associated with secondary magnetite. Relic olivine crystals and associated serpentine minerals of the awaruite-bearing serpentinite were preliminarily analyzed by means of electronprobe microanalyzer for nickel content. Average nickel content of olivine is 0.32 weight percent, while that of the serpentine is 0.15 weight percent. The result indicates that some of the nickel in substitution for $\mathrm{Mg}$ in primary olivine was liberated during serpentinization. A part of the liberated nickel was incorporated into awaruite and nickel sulphides as suggested in a awaruite-bearing serpentinite of the Eastern Townships by Nickel (1959).

In summary, the nickel content of the 
Awaruite, heazlewoodite, and native copper in serpentinized peridotite from the Mineoka district 393

awaruite and associated metallic minerals is interpreted to have been derived both from primary silicates, especially olivine, and from primary sulphide, pentlandite, of the peridotite. The nickel of primary phases was redistributed into other phases of serpentinite during serpentinization.

The temperature of serpentinization concerned is uncertain. We may assume, however, that the temperature was around $300^{\circ} \mathrm{C}$. In that temperature, the oxygen fugacity for magnetite plus awaruite equilibrium is about $10^{-42}$ bar, as calculated on the assumption that magnetite, $\mathrm{Fe}_{3} \mathrm{O}_{4}$, was in equilibrium with hypothetical nickeliron solid solution with the composition, $\mathrm{Ni}_{3} \mathrm{Fe}$. The formation of awaruite-bearing serpentinite requires some reducing condition.

The chemical reaction, which leads to serpentinization of dunite consisting of olivine with molecular composition, forsterite 3 and fayalite 1 , may be as follows.

$$
\text { Olivine Water Serpentine }
$$

$6\left(\mathrm{Mg}_{1.5} \mathrm{Fe}_{0.5}\right) \mathrm{SiO}_{4}+7 \mathrm{H}_{2} \mathrm{O}=3 \mathrm{Mg}_{3} \mathrm{Si}_{2} \mathrm{O}_{5}(\mathrm{OH})_{4}$ Magnetite $\mathrm{Hydrogen}$

$+\mathrm{Fe}_{3} \mathrm{O}_{4}+\mathrm{H}_{2}$

Hydrogen thus released can react with magnetite and olivine to produce awaruite. Magnetite Hydrogen $\mathrm{Fe}$ in Awaruite Water

$\mathrm{Fe}_{3} \mathrm{O}_{4}+4 \mathrm{H}_{2}=3 \mathrm{Fe}+4 \mathrm{H}_{2} \mathrm{O}$ Ni-olivine Hydrogen $\mathrm{Ni}$ in awaruite Silica molecule

$\mathrm{Ni}_{2} \mathrm{SiO}_{4}+2 \mathrm{H}_{2}=2 \mathrm{Ni}+\mathrm{SiO}_{2}$ Water

$+\mathrm{H}_{2} \mathrm{O}$

Silica enters into serpentine. Thus serpentinization of dunite is expressed collectively by the following reaction.

Olivine + Water $=$ Serpentine + Magnetite +
Awaruite

Under such a reducing condition pentlandite is desulphurized and iron and nickel liberated from sulphides enter into metallic phases.

\section{AGKNOWLEDGMENTS}

Field survey and preparation of thin and polished sections of the rocks were assisted by the former students of Chiba University, Messrs. F. Ishikawa, M. Yakou, Y. Miyazato, R. Yamada, M. Uchimura, N. Nakajima, Y. Matsumoto and K. Kawada. One of the writers (K.K.) wishes to express his thanks to them. Thanks are due to Prof. S. Iwao for reviewing the manuscript.

\section{REFERENGES}

Chamberlain, J.A., McLeod, C.R., Traill, R.J. and Lachance, C.R. (1965), Native metals in the Muskox intrusion. Canadian Jouv. Earth Sci., 2, $188-215$.

Colby, J.W. (1966), The applicability of theoretically calculated intensity corrections in microprobe analysis. In Electron-microprobe, edited by T.D. McKinney, K.F.J. Heinrich and D.B. Witty, 95-188.

Kanehira, K., Banno, S. and Hashimoto, M. (1964), Notes on rock-forming minerals (28) Finding of awaruite (native nickel-iron) from serpentinite near the City of Koti, Sikoku. Jour. Geol. Soc. Japan, 70, 272-277.

Nickel, E.H. (1959), The occurrences of native nickel-iron in the serpentine rock of Eastern Townships of Quebec Province. Canadian Miner., 6, 307-319.

Ramđohr, P. (1967), A widespread mineral association connected with serpentinization. Neuts Jb. Miner., Abh. 107, 241-265.

Springer, G. (1967), The correction for "continuous fluorescence" in electron-probe microanalysis. Neues Jb. Miner., Abh. 106, 241-256.

Sweatman, T.R. and Long, J.V.P. (1969), Quantitative electron-probe microanalysis of rockforming minerals. Joutr. Petrol., 10, 332-379. 
南房総嗔岡地域の蛇效岩中のアワル鉱, ヒーズルッド鉣および自然銅

兼平蛋一郎・坂野 昇平・由井 俊三

南房総镇网地域の蛇紋岩化されたカンラン岩中にアワル鉱、ヒーズルウッド鉣および自然銅が見出されだ。 とれらの鉱物は岩石中の蛇紋岩化された部分にのみ見出され，蛇紋岩化作用のときに形成されだのである。 分析されたアワル鉱の組成は $\mathrm{Ni}_{2.26} \mathrm{Fe}$ である。まだ、ヒーズルウッド鉱と共存する自然銅は数パーセントの= ッケルを含んでいる。フワル航の存在は蛇䋝岩化作用が還元的な㻴境のもとで行われたととを示している。 